\title{
Benefits and risks of protracted treatment with human recombinant erythropoietin in patients having haemodialysis
}

\author{
STEFANO CASATI， PATRIZIA PASSERINI， MARIA ROSARIA CAMPISE， GIORGIO GRAZIANI, \\ BRUNO CESANA, MICHAEL PERISIC, CLAUDIO PONTICELLI
}

\begin{abstract}
Fourteen patients with uraemic anaemia and having regular haemodialysis were given human recombinant erythropoietin in increasing doses, beginning with $24 \mathrm{U} / \mathrm{kg}$ thrice weekly. One patient was dropped from the study because of recurrent thrombosis of vascular access sites. In the other 13 patients, followed up for a mean of 9.1 months (range 8-11), haemoglobin concentrations increased from 62 (SD 8) to 105 (9) g/l. No antierythropoietin antibodies were detected during the study. The correction of anaemia was associated with a tendency to hyperkalaemia and a mild increase of unconjugated bilirubinaemia. In eight previously hypertensive patients antihypertensive treatment had to be reinforced, but in normotensive patients blood pressure did not change. Thrombosis of arteriovenous fistulas occurred in two patients and a cerebral ischaemic lesion in one.

Protracted treatment with human recombinant erythropoietin evidently can maintain normal haemoglobin concentrations in uraemic patients over time. Full correction of anaemia, however, may trigger some vascular problems, particularly in hypertensive patients and those with a tendency to thromboembolism.
\end{abstract}

Divisione di Nefrologia, Ospedale Maggiore Policlinico, 20122 Milan, Italy STEFANO CASATI, MD, assistant PATRIZIA PASSERINI, MD, assistant MARIA ROSARIA CAMPISE, MD, research fellow GIORGIO GRAZIANI, MD, senior assistant CLAUDIO PONTICELLI, MD, director

Istituto di Scienze Mediche, Ospedale Maggiore Policlinico, Milan BRUNO CESANA, MD, biostatistician

Cilag Ltd, Schaffhausen, Switzerland

MICHAEL PERISIC, MD, associate director of clinical research and development

Correspondence to: Dr Casati.

\begin{abstract}
Introduction
Several factors may contribute to the pathogenesis of uraemic anaemia but there is general agreement that inadequate secretion of erythropoietin is the main cause. ${ }^{1}$ Recently the gene coding for human erythropoietin has been isolated, characterised, ${ }^{2}$ and cloned in cultured mammalian cells. ${ }^{3}$ Two clinical studies have shown the efficacy of recombinant erythropoietin in correcting uraemic anaemia, ${ }^{45}$ but mean follow up was comparatively short. We report the results of replacement treatment with human recombinant erythropoietin given for $8-11$ months in a group of 14 patients having regular haemodialysis.
\end{abstract}

\section{Patients and methods}

Fourteen patients receiving haemodialysis who had a stable packed cell volume of less than 0.22 and had not been transfused in the past six months entered the study (table I). All gave informed consent. Dialysis was performed with a $1 \mathrm{~m}^{2}$ hollow fibre dialyser three times a week for four hours. No causes other than uraemia accounted for the anaemia. On enrolment no patient was iron deficient, as defined by serum iron and ferritin concentrations and percentage of transferrin consumption. Eight patients were taking antihypertensive agents, which maintained their mean systolic and diastolic pressures within the normal range. Six patients were normotensive without treatment.

Human recombinant erythropoietin (AMGen, Thoúsand Oaks, California) was supplied by Cilag $\mathrm{SpA}($ Milan) as a sterile buffered solution in phials containing $0.25 \%$ human albumin with a specific activity of $160000 \mathrm{U}$ human recombinant erythropoietin protein per mg. Initially the study aimed at attaining full correction of the anaemia, defined as a haemoglobin concentration of at least $120 \mathrm{~g} / \mathrm{l}$. Later, to reduce the potential hazards of rapid and full correction of the anaemia we decided to lower the target maintenance haemoglobin concentration to between 100 and $120 \mathrm{~g} / 1$.

Recombinant erythropoietin was given as an intravenous bolus at the end of dialysis three times a week. The starting dose was $24 \mathrm{U} / \mathrm{kg}$ body weight. Doses were doubled every two weeks until a mean increase in the haemoglobin concentration of at least $20 \mathrm{~g} / \mathrm{l}$ above the mean pretreatment value was achieved in three consecutive determinations. Thereafter, doses were further increased in steps of $24 \mathrm{U} / \mathrm{kg}$ every two weeks until haemoglobin concentrations were between 100 and $120 \mathrm{~g} / \mathrm{l}$. This dose was then given twice a week for two weeks. If haemoglobin concentrations tended to increase further erythropoietin was reduced to once a week for two weeks, the dose 
then being halved and given once a week for two weeks, and so on, until haemoglobin concentrations were maintained between 100 and $120 \mathrm{~g} / \mathrm{l}$.

Blood pressure, pulse rate, respiration rate, and body temperature were measured before and at the end of each dialysis and 60 minutes after each erythropoietin injection. Mean arterial pressure was calculated as diastolic pressure plus one third of the difference between systolic and diastolic pressures. Plasma urea, electrolyte, creatinine, protein, albumin, iron, and bilirubin concentrations and transaminase activities were checked weekly. Ferritin concentration, prothrombin time, and partial thromboplastin time were assessed every two weeks. Standard laboratory methods were used. Samples for haemoglobin concentrations and red cell and reticulocyte counts were collected before each dialysis and tested with a Coulter counter. Reticulocytes were counted by standard methods and corrected for red cell counts. Serum erythropoietin concentrations and formation of antierythropoietin antibody were monitored monthly in all patients by radioimmunoassay $^{56}$ at Bioscientia Laboratories (Mainz, West Germany). Parathyroid hormone values were determined with a radioimmunoassay kit (Diagnostic Products, Los Angeles). The desferrioxamine test was performed in 13 patients by the method of Simon et al. ${ }^{7}$ Plasma aluminium concentrations weekly the treatment was stopped because of recurrent thrombosis of her vascular access sites. All other patients responded to erythropoietin, though at different doses. The dosage of erythropoietin needed to increase the plasma haemoglobin concentration by $20 \mathrm{~g} / 1$ was greater in patients with high concentrations of aluminium after the desferrioxamine test $\left(F_{1,11}=\right.$ $10.30 ; p=0.0083$ ) (fig 1). No correlation, however, was found with parathyroid hormone value, patient's age, duration of dialysis, or basal plasma erythropoietin concentration (data not shown). With the increasing dosage regimen all 13 patients achieved full correction of their anaemia in 12-20 weeks. Dose or frequency of erythropoietin, or both, was then progressively reduced to maintain the haemoglobin concentration between 100 and $120 \mathrm{~g} / \mathrm{l}$ (table II).

Linear regression analysis showed a significant relation between the serum erythropoietin concentration and the haemoglobin concentration in eight of the 14 patients $(p=0.0012$ to $p=0.0374)$. In one other patient the relation just failed to reach significance $(p=0.0650)$ and in the remaining five it was not significant (fig 2). Antierythropoietin antibodies were not detected in any patient.

All patients reported great improvement in wellbeing. Asthenia, fatigue,

TABLE I-Clinical and haematological characteristics of patients at entry to study

\begin{tabular}{|c|c|c|c|c|c|c|c|c|}
\hline $\begin{array}{l}\text { Case } \\
\text { No }\end{array}$ & Sex & $\begin{array}{c}\text { Age } \\
\text { (years) }\end{array}$ & $\begin{array}{c}\text { Years of } \\
\text { haemodialysis }\end{array}$ & $\begin{array}{c}\text { Original } \\
\text { nephropathy }\end{array}$ & $\begin{array}{c}\text { Pretreatment } \\
\text { haemoglobin }(\mathrm{g} / \mathrm{l})\end{array}$ & $\begin{array}{l}\text { Serum } \\
\text { erythropoietin }(U / l)\end{array}$ & $\begin{array}{l}\text { Pretreatment mean } \\
\text { arterial pressure } \\
(\mathrm{mm} \mathrm{Hg})\end{array}$ & Native kidneys \\
\hline 1 & $\mathbf{F}$ & 50 & 16 & $\begin{array}{c}\text { Chronic } \\
\text { glomerulonephritis }\end{array}$ & 51 & 32 & $98^{\star}$ & Absent \\
\hline 2 & $\mathbf{M}$ & 30 & 14 & Alport's syndrome & 65 & 20 & 90 & Present \\
\hline 3 & M & 60 & 3 & $\begin{array}{l}\text { Chronic } \\
\text { pyelonephritis }\end{array}$ & 61 & 35 & $111^{\star}$ & Left nephrectomy \\
\hline 4 & $\mathbf{M}$ & 57 & 14 & $\begin{array}{l}\text { Chronic } \\
\text { glomerulonephritis }\end{array}$ & 65 & 42 & $101^{\star}$ & Present \\
\hline 5 & $\mathbf{M}$ & 46 & 12 & $\begin{array}{c}\text { Chronic } \\
\text { glomerulonephritis }\end{array}$ & 74 & 32 & $101^{\star}$ & Present \\
\hline 6 & F & 56 & 1 & $\begin{array}{c}\text { Chronic } \\
\text { glomerulonephritis }\end{array}$ & 70 & 24 & 98 & Present \\
\hline 7 & $\mathbf{F}$ & 53 & 11 & $\begin{array}{c}\text { Chronic } \\
\text { pyelonephritis }\end{array}$ & 57 & 20 & $105^{\star}$ & Absent \\
\hline 8 & $\mathbf{M}$ & 50 & 14 & $\begin{array}{l}\text { Chronic } \\
\text { glomerulonephritis }\end{array}$ & 57 & 35 & 102 & Absent† \\
\hline 9 & $\mathbf{F}$ & 26 & 14 & $\begin{array}{l}\text { Chronic } \\
\text { glomerulonephritis }\end{array}$ & 49 & 23 & $111^{\star}$ & Absent \\
\hline 10 & $\mathbf{F}$ & 59 & 4 & $\begin{array}{l}\text { Chronic } \\
\text { glomerulonephritis }\end{array}$ & 60 & 26 & $96^{\star}$ & Present \\
\hline $\begin{array}{l}11 \\
12\end{array}$ & $\begin{array}{l}\mathbf{M} \\
\mathbf{M}\end{array}$ & $\begin{array}{l}36 \\
35\end{array}$ & $\begin{array}{l}1 \\
1\end{array}$ & $\begin{array}{l}\text { Nephrosclerosis } \\
\text { Chronic } \\
\text { glomerulonephritis }\end{array}$ & $\begin{array}{l}68 \\
67\end{array}$ & $\begin{array}{l}24 \\
40\end{array}$ & $\begin{array}{l}122^{\star} \\
98\end{array}$ & $\begin{array}{l}\text { Present } \\
\text { Present }\end{array}$ \\
\hline 13 & $\mathbf{M}$ & 35 & 12 & $\begin{array}{c}\text { Chronic } \\
\text { glomerulonephritis }\end{array}$ & 58 & 25 & 105 & Present \\
\hline 14 & $\mathbf{M}$ & 46 & 16 & $\begin{array}{l}\text { Chronic } \\
\text { pyelonephritis }\end{array}$ & 74 & 15 & 75 & Absentt \\
\hline
\end{tabular}

^Receiving antihypertensive treatment.

tPrevious splenectomy.

were determined in triplicate by atomic absorption spectrometry with a graphite furnace ${ }^{8}$ by CISE Laboratories (Milan).

Statistical analysis-The relations between serum erythropoietin concentration and all the relevant variables and between unconjugated bilirubin and haemoglobin concentrations were investigated by simple linear regression analysis, fitted by the least squares method, applied to each patient's data. The relation between plasma aluminium concentrations and doses of erythropoietin was studied by multiple stepwise regression analysis in order to test the linear and quadratic terms of the regression equation. ${ }^{9} \log$ transformation of serum erythropoietin and aluminium values did not improve the statistical results. The behaviour of the variables recorded on several occasions was tested by analysis of variance for repeated measurements; the significance level of the $F$ statistic pertinent to the within patients factor was corrected by the Greenhouse-Geisser procedure. ${ }^{10}$ Mean arterial pressure was analysed according to a mixed factorial analysis of variance model with group, measurements (fixed factors at two and four levels respectively), and patients (random factor nested into group). The orthogonal polynomial procedure was used to test the presence of linear and quadratic trends. ${ }^{11}$ All analyses were carried out on a Univac 1100/90 mainframe computer using the SPSS X statistical package for the social sciences $^{12}$ and BMDP statistical software. ${ }^{13}$

\section{Results}

In one patient (case 10) whose haemoglobin concentration increased by only $19 \mathrm{~g} / \mathrm{l}$ after six weeks of $384 \mathrm{U}$ recombinant erythropoietin per $\mathrm{kg}$ thrice

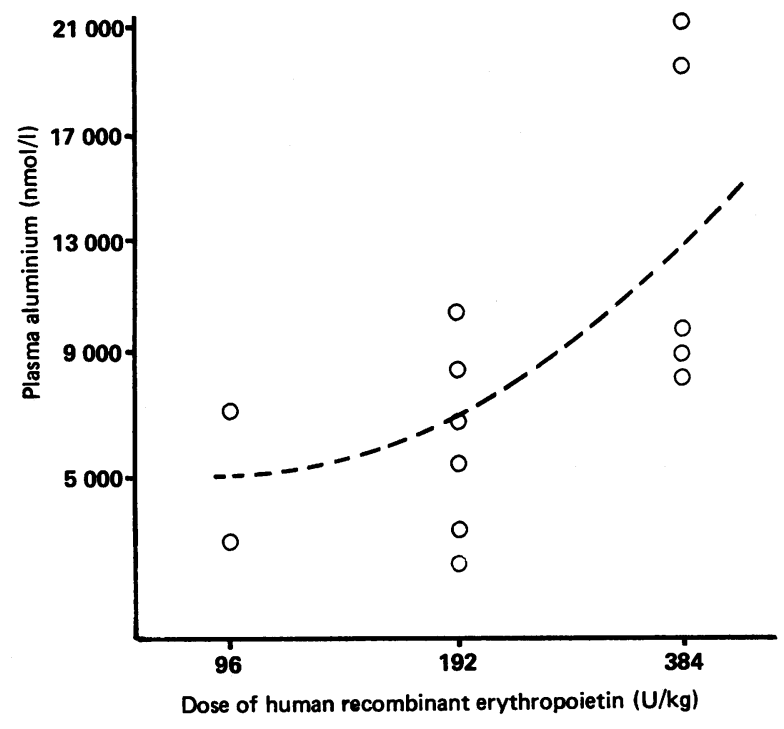

FIG 1-Relation between plasma aluminium concentration after desferrioxamine test $(40 \mathrm{mg} / \mathrm{kg}$ body weight) and dose of human recombinant erythropoietin needed to increase haemoglobin concentration by $20 \mathrm{~g} / \mathrm{l}\left(\mathrm{F}_{1}, 11=10.30\right.$; $\mathrm{p}=0.0083$; regression equation $\left.\mathrm{y}=123 \cdot 0952+1 \cdot 4554 \mathrm{E}-03 \mathrm{x}^{2}\right)$. 
TABLE II-Effects of human recombinant erythropoietin on haemoglobin concentrations and reticulocyte counts after 12-20 and 35-40 weeks of treatment ${ }^{\star}$

\begin{tabular}{|c|c|c|c|c|c|c|c|c|}
\hline $\begin{array}{c}\text { Case } \\
\text { No }\end{array}$ & $\begin{array}{c}\text { Baseline } \\
\text { haemoglobin } \\
(\mathrm{g} / \mathrm{l})\end{array}$ & $\begin{array}{c}\text { Baseline } \\
\text { reticulocyte } \\
\text { count }\left(\times 10^{9} / 1\right)\end{array}$ & $\begin{array}{l}\text { Haemoglobin after } \\
12-20 \text { weeks }(\mathrm{g} / \mathrm{l})\end{array}$ & $\begin{array}{l}\text { Reticulocyte count } \\
\text { after } 12-20 \text { weeks } \\
\left(\times 10^{9} / 1\right)\end{array}$ & $\begin{array}{c}\text { Weekly dose of } \\
\text { human recombinant } \\
\text { erythropoietin }(\mathrm{U} / \mathrm{kg})\end{array}$ & $\begin{array}{c}\text { Haemoglobin after } \\
35-40 \text { weeks }(\mathrm{g} / \mathrm{l})\end{array}$ & $\begin{array}{l}\text { Reticulocyte count } \\
\text { after } 35-40 \text { weeks } \\
\left(\times 10^{9} / 1\right)\end{array}$ & $\begin{array}{c}\text { Weekly dose of } \\
\text { human recombinant } \\
\text { erythropoietin }(\mathrm{U} / \mathrm{kg})\end{array}$ \\
\hline 1 & 51 & $14 \cdot 0$ & 131 & $39 \cdot 0$ & 1224 & 100 & $85 \cdot 6$ & 720 \\
\hline 2 & 65 & $28 \cdot 8$ & 145 & $56 \cdot 7$ & 1296 & 107 & $46 \cdot 3$ & 288 \\
\hline 3 & 61 & $18 \cdot 1$ & 136 & $48 \cdot 4$ & 864 & 105 & $25 \cdot 1$ & 288 \\
\hline 4 & 65 & 10.9 & 124 & 55.4 & 1296 & 104 & $38 \cdot 7$ & 720 \\
\hline 5 & 74 & $17 \cdot 5$ & 127 & $68 \cdot 4$ & 1224 & 116 & $50 \cdot 3$ & 624 \\
\hline 6 & 70 & $28 \cdot 7$ & 121 & $34 \cdot 3$ & 720 & 115 & $25 \cdot 8$ & 240 \\
\hline 7 & 57 & $13 \cdot 5$ & 127 & $46 \cdot 4$ & 1296 & 102 & $21 \cdot 4$ & 312 \\
\hline 8 & 57 & $10 \cdot 7$ & 108 & $44 \cdot 8$ & 796 & 113 & $15 \cdot 3$ & 66 \\
\hline 9 & 49 & $57 \cdot 5$ & 104 & $19 \cdot 9$ & 720 & 80 & 14.6 & 432 \\
\hline $10+$ & 60 & $7 \cdot 5$ & 79 & $32 \cdot 6$ & 1296 & & Dropped out & \\
\hline 11 & 68 & $13 \cdot 2$ & 128 & $26 \cdot 3$ & 432 & 106 & 26.5 & 120 \\
\hline 12 & 67 & 21.9 & 115 & $58 \cdot 3$ & 504 & 108 & $48 \cdot 8$ & 168 \\
\hline 13 & 58 & $18 \cdot 7$ & 107 & $19 \cdot 9$ & 648 & 107 & $22 \cdot 3$ & 108 \\
\hline 14 & 74 & $7 \cdot 9$ & 108 & $23 \cdot 8$ & 648 & 114 & 15.9 & 108 \\
\hline $\begin{array}{l}\text { Mean } \\
\text { SD }\end{array}$ & $\begin{array}{r}62 \\
8\end{array}$ & $\begin{array}{l}20 \cdot 1 \\
12 \cdot 9\end{array}$ & $\begin{array}{r}121 \\
12\end{array}$ & $\begin{array}{l}41 \cdot 6 \\
15.9\end{array}$ & $\begin{array}{l}897 \\
324\end{array}$ & $\begin{array}{r}105 \\
9\end{array}$ & $\begin{array}{l}33 \cdot 6 \\
20 \cdot 1\end{array}$ & $\begin{array}{c}322 \\
23\end{array}$ \\
\hline
\end{tabular}

Quadratic trends for haemoglobin concentration and reticulocyte count (analysis of variance): $F_{1,12}=94 \cdot 67, p<0 \cdot 000001 ;$ and $F_{1,12}=10 \cdot 29, p=0 \cdot 0076$. *Cases 8-14 entered into study after decision to reduce correction of anaemia to haemoglobin concentrations of $100-120 \mathrm{~g} / \mathrm{l}$. tCase 10 excluded from calculations of mean and SD.

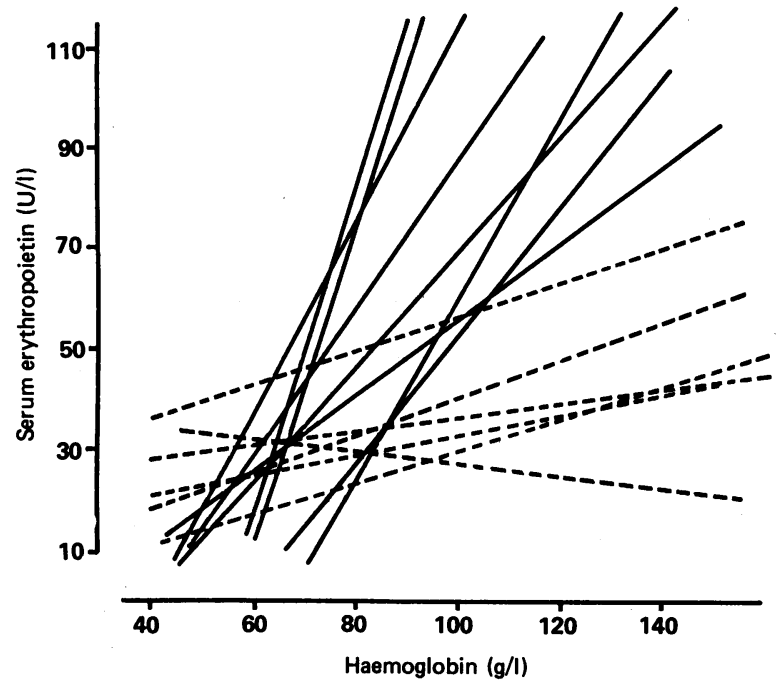

FIG 2-Relation between serum erythropoietin concentration and haemoglobin concentration in 14 patients given increasing doses of human recombinant erythropoietin. Relation was significant in eight patients (- $-p=0.0012$ to $p=0.0374)$ and not significant in six (-.-.----).

headache, and tachycardia disappeared and many patients returned to work or began new physical activities. A substantial improvement in appetite was reported, and in one patient ideal body weight increased by $2 \mathrm{~kg}$. Angina pectoris, which had been reported occasionally by two patients before the study, no longer occurred after correction of the anaemia.

Recombinant erythropoietin was stopped temporarily in four patients - in two (cases 2 and 3 ) because of a haemoglobin concentration greater than $140 \mathrm{~g} / \mathrm{l}$, in one (case 4) because of reversible focal cerebral ischaemia when the haemoglobin concentration was $122 \mathrm{~g} / 1$, and in one (case 9) because of hypertension refractory to treatment. In these patients haemoglobin concentrations (mean 126 (SD 17) $\mathrm{g} / \mathrm{l}$ ) remained stable for two weeks after stopping erythropoietin $(120(12) \mathrm{g} / \mathrm{l})$, then slowly decreased over two weeks to 107 (9) $\mathrm{g} / \mathrm{l}$, and fell to 97 (9) $\mathrm{g} / \mathrm{l}$ six weeks later. The 13 responders required a mean heparin dose of 1071 (SD 335) U/hour in the pretreatment period and a mean dose of 1558 (486) U/hour at full correction of the anaemia $\left(F_{1,12}=24.01 ; p=0.0004\right)$.

Plasma urea, creatinine, protein, sodium, calcium, and phosphate concentrations did not change significantly during follow up.

\section{SIDE EFFECTS}

In normotensive patients the mean arterial pressure did not change, whereas antihypertensive treatment had to be reinforced in the hypertensive group. In some patients the dosage of antihypertensive drugs was doubled, and in others further antihypertensive drugs were added to treatment (fig 3 ) In three patients unpredictable hypertensive spikes occasionally occurred.

Predialysis potassium concentrations tended to increase with the increment of haemoglobin, so that cationic exchange resins had to be given to 11 patients, who had a mean predialysis potassium concentration higher than $5.8 \mathrm{mmol} / \mathrm{l}$. Mean pretreatment total bilirubin concentration (9.4 (SD 3.4) $\mu \mathrm{mol} / \mathrm{l}$ ) increased, though not significantly, at correction of anaemia to 14.0 $(8.55) \mu \mathrm{mol} / \mathrm{l}$. This increment in bilirubin was mainly due to an increase in the unconjugated fraction-5.3 (2.73) $\mu \mathrm{mol} / \mathrm{l}$ before treatment; 8.71 (6.83) $\mu \mathrm{mol} / 1$ at $25 \%$ of total desired haemoglobin increment; $9 \cdot 74(6 \cdot 49) \mu \mathrm{mol} / 1$ at $50 \%$ of haemoglobin increment; $10.9(5 \cdot 1) \mu \mathrm{mol} / \mathrm{l}$ at full correction of anaemia $\left(F_{3}, 36=8 \cdot 28 ; p=0.0008\right)$. Owing to a significant reduction of plasma iron $\left(F_{1,12}=21.09 ; p=0.0006\right)$ during erythropoietin treatment iron supplementation was required by 13 patients (table III).

Three patients complained of bone pain, fever, sweating, shivers, and abdominal cramps, which they described as a "flu-like syndrome." The symptoms appeared 90-120 minutes after any intravenous bolus of erythropoietin and disappeared spontaneously within 10-12 hours. Five patients showed conjunctival inflammation very similar to uraemic "red eye," which occurs with ocular ectopic calcification. This sign, however, was completely asymptomatic and had no relation to plasma calcium or phosphate concentrations. One patient (case 2) had a thrombosis of his arteriovenous fistula, which had been functioning for 10 years, when his packed cell volume increased from 0.18 to 0.40 . Another patient (case 10) had episodes of

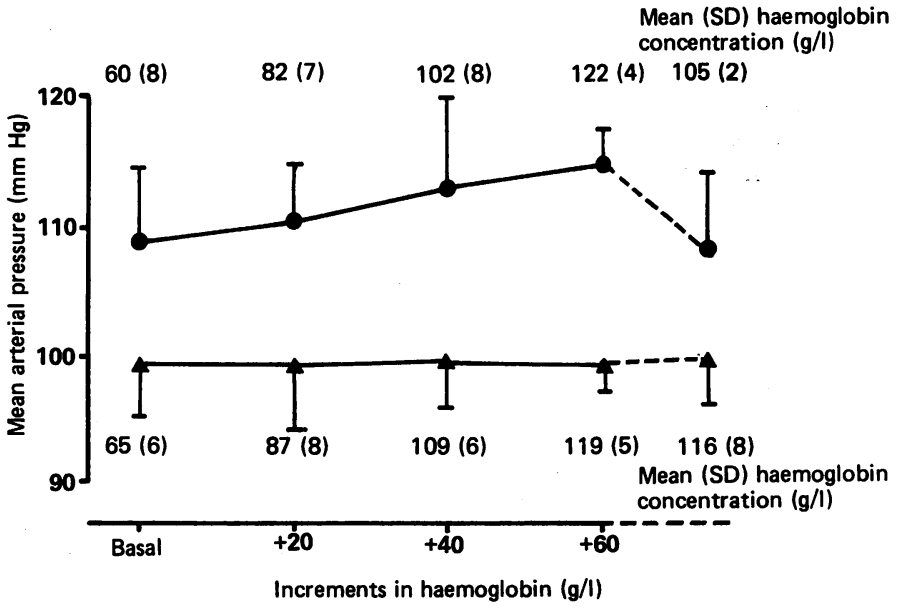

FIG 3-Variations in mean arterial pressure at different increments of haemoglobin concentration during treatment with human recombinant erythropoietin. $\Delta=$ Patients with normal blood pressure before treatment with erythropoietin. = Patients receiving antihypertensive agents before treatment with erythropoietin. After full correction erythropoietin doses were adjusted to maintain stable haemoglobin values in normotensive patients and lower haemoglobin values in hypertensive patients (--------). Significance of difference between groups: $\left.F_{1}, 11=22 \cdot 11 ; p=0.0006\right)$. No differences found within groups at different times of treatment. 
thrombosis of two proximal fistulas plus thrombosis of left subclavian and right femoral vein.

One patient (case 4) developed neurological symptoms. Before the study this patient had been taking $120 \mathrm{mg}$ propranolol and $75 \mathrm{mg}$ hydralazine daily for hypertension. The increase in haemoglobin concentration from 65 to 122 $\mathrm{g} / \mathrm{l}$ was accompanied by an increase in blood pressure (mean arterial pressure rose from 102 to $113 \mathrm{~mm} \mathrm{Hg}$ ), which was treated with an additional $60 \mathrm{mg}$ nifedipine daily. Mean arterial pressure remained around $108 \mathrm{~mm} \mathrm{Hg}$.

TABLE III-Serum iron and ferritin concentrations at start of recombinant erythropoietin treatment and at full correction of anaemia

\begin{tabular}{|c|c|c|c|c|c|}
\hline \multirow[b]{2}{*}{$\begin{array}{c}\text { Case } \\
\text { No }\end{array}$} & \multicolumn{2}{|c|}{$\begin{array}{l}\text { Before treatment } \\
\text { (haemoglobin } \\
\left.62\left(\mathrm{SD}_{)}\right) \mathrm{g} / \mathrm{l}\right)\end{array}$} & \multicolumn{2}{|c|}{$\begin{array}{c}\text { At correction of } \\
\text { anaemia (haemoglobin } \\
121(\text { SD 12) g/l) }\end{array}$} & \multirow{2}{*}{$\begin{array}{c}\text { Cumulative } \\
\text { intravenous iron } \\
\text { supplementation (mg) }\end{array}$} \\
\hline & $\underset{(\mu \mathrm{mol} / \mathrm{l})}{\text { Iron }}$ & $\begin{array}{c}\text { Ferritin } \\
(\mu \mathrm{g} / \mathrm{l})\end{array}$ & $\begin{array}{c}\text { Iron } \\
(\mu \mathrm{mol} / \mathrm{l})\end{array}$ & $\begin{array}{c}\text { Ferritin } \\
(\mu \mathrm{g} / \mathrm{l})\end{array}$ & \\
\hline 1 & $14 \cdot 1$ & 850 & $11 \cdot 1$ & 850 & $1126 \cdot 8$ \\
\hline 2 & $23 \cdot 1$ & 305 & $15 \cdot 7$ & 292 & 876.4 \\
\hline 3 & $16 \cdot \overline{4}$ & 314 & $10 \cdot 7$ & 160 & $1439 \cdot 8$ \\
\hline 4 & $12 \cdot 3$ & 96 & 10.0 & 60 & $1064 \cdot 2$ \\
\hline 5 & 13.9 & 104 & $12 \cdot 7$ & 42 & $1808 \cdot 4$ \\
\hline 6 & $13 \cdot 4$ & 34 & 9.8 & 63 & $2367 \cdot 4$ \\
\hline 7 & $12 \cdot 3$ & 108 & $11 \cdot 1$ & 75 & $1878 \cdot 0$ \\
\hline 8 & $17 \cdot 2$ & 94 & $12 \cdot 7$ & 169 & $1247 \cdot 8$ \\
\hline 9 & 20.0 & 628 & 10.5 & 269 & \\
\hline 10 & $11 \cdot 1$ & 30 & \multicolumn{2}{|c|}{ Dropped out } & 503.4 \\
\hline 11 & $13 \cdot 4$ & 480 & $9 \cdot 1$ & 115 & $1061 \cdot 2$ \\
\hline 12 & $13 \cdot 8$ & 71 & $13 \cdot 6$ & 95 & $1306 \cdot \overline{2}$ \\
\hline 13 & $12 \cdot 9$ & 73 & $13 \cdot 4$ & 22 & 2982.6 \\
\hline 14 & $14 \cdot 1$ & 94 & 8.6 & 58 & $3250 \cdot 4$ \\
\hline
\end{tabular}

Pretreatment ferritin concentration $v$ concentration at correction of anaemia: $\mathrm{F}_{1,12}=3 \cdot 88$; $\mathbf{p}=\mathbf{0} \cdot 075$.

During a dialysis he developed aphasia and confusion. Cerebral computed tomography excluded haemorrhages but showed a small area with an ischaemic lesion. Antiplatelet treatment (aspirin $100 \mathrm{mg} /$ day) was given and erythropoietin stopped, and within 10 days the aphasia and confusion had completely remitted. Erythropoietin was reintroduced, maintaining the haemoglobin concentration between 105 and $110 \mathrm{~g} / \mathrm{l}$, and six months later there had been no further complications.

\section{Discussion}

Human recombinant erythropoietin has recently been made available for clinical trials and two pilot studies have shown that it can fully correct anaemia in patients receiving haemodialysis. ${ }^{45}$ Our findings confirm this. Nevertheless, the dosage required to increase the haemoglobin concentration in our patients ranged widely. Though age, duration of dialysis, basal plasma erythropoietin concentration, and parathyroid hormone concentration did not influence the response to erythropoietin, we found a negative correlation between the response in the desferrioxamine test and the response to erythropoietin. This suggests that deposition of aluminium in bone may impair the bone marrow response to erythropoietin. On the other hand, the data also show that aluminium intoxication does not exclude the possibility of correcting anaemia with erythropoietin but simply means that a higher dosage is required.

Reductions in transferrin consumption, serum ferritin concentrations, and especially plasma iron concentrations were recorded during erythropoietin treatment, probably as a consequence of the rapid increase in the synthesis of haemoglobin. Iron supplementation is therefore needed during treatment with erythropoietin to prevent iron and ferritin depletion, which might alter the response to erythropoietin.

As expected, the correction of anaemia was accompanied by a substantial improvement in patients' rehabilitation and quality of life, which was maintained over the period of the study. Nevertheless, side effects also occurred. As in the series of Eschbach et al, ${ }^{5}$ most of our patients had a predialysis increase in serum potassium concentration, which almost universally required the regular use of cationic exchange resins during the whole period of follow up.
Hyperkalaemia may have been due to improved appetite with $\underline{\underline{T}}$ increased potassium in the diet or to increased release of potassium 3 into the plasma from a greater number of red cells haemolysed daily, $\triangle$ as suggested indirectly by the increased concentrations of unconjugated bilirubin in the plasma found in all patients. Whatever the cause the risks of possibly dangerous hyperkalaemia during treatment with erythropoietin should be kept in mind.

Though normotensive patients did not show any variation in blood pressure during erythropoietin treatment, in the hypertensive group the correction of anaemia required more vigorous antihypertensive measures. The rise in blood pressure during erythropoietin treatment may be attributable to the increased blood viscosity and total red cell mass, inducing an increase in peripheral resistance ${ }^{14} \mathrm{It}$ has also been suggested that anaemia may induce a hypoxic peripheral vasodilatation. If so the correction of anaemia might be accompanied by increased arteriolar resistance, which would worsen hypertension. ${ }^{15}$ Despite reinforcement of antihypertensive treatment mean arterial pressure tended to rise in our hypertensive patients with increasing haemoglobin concentrations. Only after erythropoietin dosage was adjusted to keep haemoglobin concentrations around $105 \mathrm{~g} / \mathrm{l}$ did the mean arterial pressure fall in this group. A tendency to vascular thrombosis was also seen in some patients. This may be due either to increased blood viscosity or to the fact that correction of anaemia may shorten the prolonged bleeding time in uraemic patients. ${ }^{16}$

Severe anaemia is one of the most distressing complications of uraemia. It is responsible for asthenia, dyspnoea, tachycardia, headache, reduced appetite, and dizziness and in some cases may precipitate cardiac failure. Nevertheless, teleologically anaemia may serve as a protective factor against cardiovascular complications as it allows better control of hypertension and reduces platelet adhesiveness. In epidemiological studies patients with mild anaemia had less cardiovascular disease, while mortality was higher in subjects with high packed cell volumes. ${ }^{17}$ We suggest that, particularly in patients with arterial hypertension, erythropoietin should initially be given in small doses with small increments to avoid too rapid correction of the anaemia. Moreover, haemoglobin concentrations should be kept around $100 \mathrm{~g} / \mathrm{l}$. This "partial correction," while sufficient to reverse most of the symptoms of anaemia, should avoid the risk of increased blood pressure and thrombosis. In patients with refractory hypertension and repeated episodes of thrombosis even lower concentrations of haemoglobin might be considered in order to prevent cardiovascular complications. With these precautions it is unlikely that erythropoietin will trigger important side effects.

\section{References}

Adamson JW, Eschbach JW, Finch CA. The kidney and erythropoietin. Am f Med 1968:44: 725-33.

2 Jacobs $\mathrm{K}$, Shoemaker $\mathrm{C}$, Rudersdorf $\mathrm{R}$, et al. Isolation and characterization of genomic and cDNA clones of human erythropoietin. Nature 1985;313:806-10.

3 Lin FK, Suggs S, Lin CH, et al. Cloning and expression of human erythropoietin gene. Proc Na Acad Sci USA 1985;82:7580-4.

4 Winearls CG, Pippard MJ, Downing MR, Oliver DO, Reid C, Cotes PM. Effect of human erythropoietin derived from recombinant DNA on the anaemia of patients maintained by chronic haemodialysis. Lancet 1986;ii:1175-7.

5 Eschbach JW, Egrie JC, Downing MR, Browne JK, Adamson JW. Correction of the anemia of end stage renal disease with recombinant human erythropoietin. N Engl 7 Med 1987;316:73-8. 6 Egrie JC, Cotes PM, Lane S, Gaines Dos RE, Tam RC. Development of radioimmunoassays fo human erythropoietin using recombinant erythropoietin as tracer and immunogen. $f$ Immunol Methods 1987;99:235-41.

7 Simon P, Ang KS, Tanquerel T, Allain P, Mauras Y. Surcharge tissulaire en aluminium chez les hemodialyses. Test à la desferrioxamine. Nouv Presse Med 1982;2:209-14.

8 Gorsky JE; Dietz AA. Determination of aluminium in biological samples by atomic absorption spectrometry with a graphite furnace. Clin Chem 1978;24:1485-91.

9 Draper N, Smith H. Applied regression analysis. 2nd ed. New York: John Wiley and Sons, 1981.

10 Geisser S, Greenhouse SW. An extension of Box's results on the use of the F distribution in multivariate analysis. Annals of Mathematical Statistics 1958;29:885-91.

11 Winer BJ. Statistical principles in experimental design. 2nd ed. New York: McGraw-Hill, 1971.

12 Norman HN. SPSS-X statistical package for the sacial sciences. New York: McGraw-Hill, 1983.

13 Dixon WJ. BMDP statistical software. Berkeley: University of California Press, 1981.

14 Neff MS, Kim KE, Persoff M, Onesti G, Swartz C. Hemodynamics of uremic anemia. Circulation 1971;43:876-83.

15 Coleman TG. Hemodynamics of uremic anemia. Circulation 1972;45:510-1.

16 Livio M, Marchesi D, Remuzzi G, Gotti E, Mecca G, De Gaetano G. Uraemic bleeding: role of anaemia and beneficial effect of red cell transfusions. Lancet 1982;ii:1013-5.

17 Elwood PC, Waters WE, Benjamin IT, Sweetnam PM. Mortality and anaemia in women. Lancet 1974;i:891-4

(Accepted 16 September 1987) 